\title{
Incorporating Academic Writing Phrases into EFL Students' Research Proposals
}

\author{
Anselmus Sudirman \\ Universitas Sarjanawiyata Tamansiswa, Yogyakarta, Indonesia \\ https://orcid.org/0000-0001-5520-9838 \\ Adria Vitalya Gemilang \\ Universitas Sarjanawiyata Tamansiswa, Yogyakarta, Indonesia \\ https://orcid.org/0000-0002-7784-7811 \\ Hendrikus Male \\ Universitas Kristen Indonesia, Jakarta \\ https://orcid.org/0000-0002-4424-7852
}

\begin{abstract}
The phrasal expressions in research proposals represent an integral semantic unit coherently, including the basic academic phrases and syntactic elements. The objectives of this research are (1) to describe the types of academic writing phrases in EFL students' research proposals, (2) to find out the benefits of academic writing phrases, and (3) the problems that EFL students faced while constructing academic writing phrases. This interpretive/qualitative research seeks to identify, classify, and analyse data pertaining to the academic writing phrases in 28 research proposals. The results show the academic writing phrases that are organised into introducing the topic using specific writing phrases and guidelines, identifying the significance of the issue, the scopes and objectives of the research, the review of literature, and the explanation of key terms. These contributions confirm the benefits of academic writing phrases for educational purposes, namely to pursue knowledge of EFL writing, encourage self-confidence, support self-awareness and modify writing practices. As reflected through the interview results, however, EFL students are afraid of making mistakes, and they find it hard to explore ideas and use academic writing phrases to enhance linguistic advancement, metalinguistic knowledge, phrasal familiarity, clarity, and acceptability. The pedagogical implications of the findings merit further considerations.
\end{abstract}

Keywords: writing; academic writing; academic writing phrases; EFL students; research proposals 


\section{Introduction}

The primary focus of this research is to examine three areas in academic writing that challenge EFL students to explore academic writing across contexts (Qin \& Uccelli, 2020). First, the phraseological praxis in academic writing articulates a mode of academic phrases. The term academic, in a broad sense, puts forward theoretical and practical grounds of writing phrases and their relevant contributions to the organization of ideas. Second, academic writing phrases in the introductory part of a research proposal comprise the background information of issues, research objectives, research questions, hypotheses, and the synopsis of methodological platforms. Distinctive categories of academic phrases (Davis \& Morley, 2015) reflect typical orders - fixed or more flexible, depending on the complexity of issues under discussion (Morley, 2015). Thus, most academic writers deal with academic phrases that help them make a difference in writing a research proposal.

Academic writing phrases put more emphasis on interlingual transfer of idioms, and collocations (Afshunpour \& Memari, 2014; Chen, 2019). The unit of phrasal expressions designates a coherent semantic unit including base-phrase chunking and syntactic constraints (Kozawa, Sakai, Sugiki \& Matsubara, 2010). Besides, academic words or phrases (Akbari, 2017) can be found in the research proposal formats, guidelines, and section class identifications. Both common words and phrasal expressions are based on the locality classification that underline the frequency of academic writing phrases in each section. As academic writing has been a major concern for non-native speakers of English, they encounter difficulties in communicating verbal ideas (Kozawa, Sakai, Sugiki \& Matsubara, 2010), and using academic writing phrases. Consequently, they cannot improve their grammatical performances, organizations of ideas, writing quality (Abbas, Hammad, Hwang, Khan \& Gilani, 2020), and linguistic expressions (Qin \& Uccelli, 2020).

Other researchers have identified several problems concerning the use of academic writing phrases in EFL contexts. In terms of phraseological area, EFL students tend to use unclear collocations and phrases in the pedagogical corpora widely incorporated into teaching materials (Oakey, 2020). In what follows, there is a growing gap between the stocks of phrases and the way they are either taught or used in the classroom. For example, lexical bundles in specific contexts (Hyland, 2008) do not contain lexical words, giving rise to the difficulties in understanding academic writing phrases (Oakey, 2020), and less focused classroom interactions (Parkinson \& Musgrave, 2014) account for the dynamics of writing performances.

EFL students keep a firm commitment to use academic writing phrases in a wide variety of writing practices. Without mastering academic writing phrases, they may lead to a degree of writing complexity and the communication of ideas fails to be expressed as clearly as possible. Most students write in the EFL environment that is more or less influenced by their mother tongues, in this case, Indonesian language or other local languages. The outcome of their writing seems uncommon to native speakers of English because of inter-lingual errors (Elfiondri, 2019) and inter-lingual interference involving a translation strategy in a mother tongue 
domain (Kaweera, 2013), and the unfamiliar use of certain academic writing phrases.

In response to such fundamental issues, this research seeks to frame three questions, as follows:

1. What are the types of academic writing phrases in EFL students' research proposals?

2. What benefits do EFL students obtain from constructing academic writing phrases in the research proposals?

3. What problems do EFL students face while constructing academic writing phrases in the research proposals?

\section{Literature Review}

\section{Academic Writing}

Academic writing is an appropriate course for college or university students (Bailey, 2015; Habibie, 2019; Mur-Dueñas, 2019; Casanave, 2019) because of its high level of complexity, targeted audience, purpose, and tone. Unlike literary, personal, or journalistic style of writing, academic writing pays more attention to the diction, formality of tone, grammatical rules, etc. that may influence the clarity, and objectivity of messages transferred formally and impersonally.

Concerning a tone, Badley (2020) offers an insight into the use of formal language by avoiding informality including sentence fragments, exclamations, initials (and, but, or so), and modality contractions. Academic writing aims to persuade, explain, or convince audiences about the correct claims on relevant issues, and its processes entail prewriting, planning, searching references, handling references, data collection and analysis, and writing and revising drafts. In the prewriting stage, EFL students are required to choose a topic and narrow it down. Brainstorming ideas (Boddy, 2012) is a process of listing concepts in free-writing activities, and clustering sessions of writing. Topical options in academic writing refer to how the practicality of course descriptions contributes to the time management involving motivation, future research concern, and thematic domains that narrow down the gamut of topics, location, subject, timeline, etc. These attributes determine the construction of lexical phrases (Li \& Schmitt, 2009) to pursue a convincing argument so that the practice of writing in a more extensive scope is worth considering.

The construction of the phrases is closely connected to EFL students' writing competence in patterning sentences, and grammatical components (Staples, Egbert, Biber \& Gray, 2016). The ability to combine clauses and nouns emerged before prepositional bundles (Ruan, 2017) is of paramount importance. Furthermore, EFL students' literacy on academic writing depends wholly on the understanding of the lexical phrases that might shift from the low and medium level of awareness to the high-level one (Çandarlı, 2018).

\section{Academic Writing Phrases}

The integrated practices of constructing academic writing phrases have long been touted as the advancement of background knowledge (Morley, 2015). Each academic writing phrase has componential parts of generally accepted expressions that likely identify a range of writing topics, tasks and genres 
(Rakedzon \& Baram-Tsabari, 2017), collaboration, audience awareness, flexibility, and information sharing (Barrot, 2020) in the 21 $1^{\text {st }}$ century. Academic writing phrases also deal with linguistic complexities, self-awareness, and understanding of issues (Abednia, Hovassapian, Teimournezhad \& Ghanbari, 2013). In short, academic writing phrases establish emerging issues and self-exploratory stages to connect theories and practices of writing.

Another critical point to consider is that academic writing phrases play a pivotal role in shaping EFL students' writing (cognitive) performances (Teng, 2019; Farahian \& Avarzamani 2018; Birjandi \& Tamjid, 2012) through the revision behaviour, time on task, pause behaviour, pausing strategy (Zarrabi \& Bozorgian, 2020). In most cases of EFL contexts, consistent practices of academic writing can be modified to enhance writing competence (Bai, Wang \& Nie, 2020; Beck \& Jeffery, 2007), and factual achievement in developing critical ideas. Instead, little attention has been paid to the integrated practices of academic writing phrases in research proposals for EFL university students. In short, a metalinguistic understanding of lexical phrases is necessary to change EFL students' selfawareness from the low and medium level to the high level one, depending on the variability (Çandarl1, 2018) within the intended research proposals.

In contrast, Badley (2019) argues that academic writing has a strict system for generating jargon and over-theoretical approaches. The overemphasis on theories leads to tangent criticism that writers and researchers find it hard to stay open and accessible to a more progressive style of writing. Post-academic writing (Badley, 2020; Badley, 2019) is a term that emphasizes a humanity message for human readers in contexts. This notion is that EFL students learn to write as they want to become post-academic writers in the future. The use of phrases in EFL students' academic writing across different levels reflects a consistency to achieve desired writing performances. EFL students prefer to employ more academic writing phrases (Thonney, 2012) because they want to advance toward a higher level of competence (Ruan, 2017) and academic writing skills (Imaniah, Mayuni \& Lustyantie, 2019).

\section{Academic Writing Phrases in Research Proposals}

In the practice of writing research proposals, academic phrases play a pivotal role in constructing sentences sequentially (Vincent, 2013), and setting basic strategies to distinctively feature lexical bundles used in the novice writing (Ruan, 2017). These key factors strengthen the advancement of academic writing and the acceptability of research proposals compiled by EFL students. Several studies show that students' complicated noun phrases in research proposals aim to describe the English language proficiency for academic purposes (Parkinson \& Musgrave, 2014), popular science writing skills (Rakedzon \& Baram-Tsabari, 2017), phraseological patterns, semantic and pragmatic divergences (Nuccorini, 2006), and lexical phrases (Li \& Schmitt, 2009). The use of phraseological patterns is likely to indicate a non-native manner of learning resulting from the text level of difficulties (Leroy, Kauchak \& Hogue, 2016), students' lack of vocabulary, grammar, and background knowledge.

In some cases, the quality of phraseological expressions in a text impacts the quality of other documents as a whole (Rojo, 2018). The quality of an academic 
version rests on the accuracy and fluency, grammatical complexity, and proficiency of writing (Lan, Lucas \& Sun, 2019; Lan \& Sun, 2019). The models of academic writing phrases are used in situational contexts (Kerz \& Wiechmann, 2015) in response to how university students write texts that functionally outline lexical phrases (Li \& Schmitt, 2009; DeCarrico \& Nattinger, 1988). Without intense practices regularly, however, EFL students cannot produce native-like academic writing phrases.

Critical points in much of the literature indicate that EFL students tend to copy and use other writers' words or phraseological phrases (Davis \& Morley, 2015). This plagiarism can be prevented through the phraseological detections of phrases at "the basic level of categorization" (Clifton \& Frazier, 2012), and lexical phrases in the academic genre (Cai, 2016). As a consequence, EFL students are encouraged to produce new but original expressions in an academic discourse level (Benelhadj, 2019). The correct use of academic writing phrases in sentences and paragraphs determines the accuracy, fluency, syntactic complexity (Ansarifar, Shahriari \& Pishghadam, 2018), grammatical complexity (Biber, Gray, Staples \& Egbert, 2020), and linguistic complexity (Qin \& Uccelli, 2020) of expressions in the research proposals.

As a linguistic phenomenon, the phrasal verbs represented in a written form combine students' knowledge, practice, and writing skills. This is because [EFL] students (Rahman, 2013) have difficulties in demonstrating such fundamental skills to increase writing competence (Kelso, 2018; Ratminingsih, Marhaeni \& Vigayanti, 2018; Miller, Grise-Owens, Drury \& Rickman, 2018; Berge, Evensen \& Thygesen, 2016; Surmann, 1997). Therefore, it is necessary to pursue a metalinguistic domain of lexical phrases, namely low and medium level awareness of academic phrases (Çandarl, 2018) to map out EFL students' writing performances. The objective of Çandarlı's research is to accentuate the L1Turkish-speaking, first-year university students' metalinguistic knowledge of the lexical phrases in academic writing. The research's novelty promotes to what extent lexical phrases support academic writing activities (Powers, Fowles \& Welsh, 2001; Golpour, Ahour, Ahangari \& Lu, 2019) in higher education. In one way or another, this metalinguistic knowledge (Myhill, Jones \& Wilson, 2016) can be acquired to gain new understandings of academic writing phrases in diverse contexts.

Other studies on academic writing phrases highlight that Chilean students write locally coherent persuasive texts to grasp the local coherence (LC) that seeks to identify students' reasons, arguments and opinions in academic writing (Concha \& Paratore, 2011). Hence, there is an urging demand for metalinguistic knowledge to moderate the constructions of concepts and operationalize students' abilities to correct, describe, and explain errors (Roehr, 2008) in academic written English (Liu \& Myers, 2020). Metalinguistic knowledge contributes to the practical use of lexical bundles (Wei \& Lei, 2011), syntactic complexity of assignments (Mostafa \& Crossley, 2020), modelling, deconstructions of texts (Nagao, 2019), and lexical phrases in academic writing ( $\mathrm{Li} \& \mathrm{Schmitt,} \mathrm{2009).} \mathrm{It} \mathrm{is} \mathrm{imperative} \mathrm{that} \mathrm{EFL}$ students are aware of those requirements to increase their proficiency of academic writing phrases and build a strong theoretical foundation of writing, language 
performance (Smith, 2004), language resources, and pedagogical conversations (Galloway, Stude \& Uccelli, 2015).

\section{Research Method Type of the Study}

This interpretive/qualitative research (Sosenko, 2012) emphasizes the interpretation of documents (the introductory and literature review sections of EFL university students' research proposals). Open-ended interviews seek to elicit more information on the benefits of and problems in constructing the academic writing phrases.

\section{Research Setting}

This research was undertaken at the English Education Department of Universitas Sarjanawiyata Tamansiswa, Yogyakarta, Indonesia involving fourth semester students' research proposals $(\mathrm{N}=28)$ out of 30 total populations (Cohen, Manion, $\&$ Morrison, 2000). It was conducted within six months starting from February to June 2019, concentrating on the praxis of academic writing phrases in EFL students' research proposals.

\section{Research Instrument}

The research instruments included (1) documents, in this case, the research proposals in three different fields, such as EFL, linguistics, and literature, and (2) the interview documents of 11 EFL students used to elicit information on the critical reflection and reflexivity (Mann, 2016), and emerging views on theories and practices (Willis, 2015) of academic writing phrases. The sampling design of the interview is specifically enumerated since the total population can often be interviewed, and rarely exceeds 15 and 25 recognizable participants (Trotter, 2012; Crouch \& McKenzie, 2006).

The processes of developing the validity and reliability of research instruments include investigating the quality of interpretative frames, distinguishing between perceived problem definitions, identifications, proposed solutions, empirical background theories, and normative preferences (Moret, Reuzel, van der Wilt \& Grin, 2007). Researchers also evaluated the utility of research instruments by implementing verification strategies, and self-correcting during the conduct of inquiry, engaging trustworthiness techniques to assess their quality and credibility (Morse, Barrett, Mayan, Olson \& Spiers 2002; Rose \& Johnson, 2020).

To verify the validity and reliability of the interview data, the researchers described participants' perspective, reformulated interpretative frames of verbatim transcripts and data coding, reconstructed a method for analysing the interview scripts (Moret et al., 2007), and incorporated social reliability into the research instrument to enrich understandings of the emerging phenomena (Sanders \& Cuneo, 2010).

\section{Data Collection Technique}

Audio-recorded interviews with 11 out of 28 participants were conducted to gain essential information on the benefits of and problems in constructing the academic writing phrases in research proposals. The duration of interviews with participants ranged from 30 to 45 minutes, followed by the clarification of 
responses before the final stage of interview data transcriptions, as viewed from the following table.

Table 1. The participants' profiles and views on the academic writing phrases and problems emerged

\begin{tabular}{|c|c|c|c|c|c|}
\hline No & $\begin{array}{l}\text { Names } \\
\text { by } \\
\text { Initials }\end{array}$ & Gender & Interests & Views & Problems \\
\hline 1 & $\mathrm{HN}$ & M & EFL & $\begin{array}{l}\text { - Pursue knowledge of EFL } \\
\text { writing } \\
\text { - Improve writing } \\
\text { competence }\end{array}$ & $\begin{array}{l}\text { Getting } \\
\text { started with a } \\
\text { few lines }\end{array}$ \\
\hline 2 & ANM & M & EFL & $\begin{array}{l}\text { - Encourage self-confidence } \\
\text { - Challenge writing } \\
\text { accuracies }\end{array}$ & $\begin{array}{l}\text { Fear of } \\
\text { making } \\
\text { mistakes }\end{array}$ \\
\hline 3 & $\mathrm{AP}$ & $\mathrm{F}$ & Literature & $\begin{array}{l}\text { - Hone writing skills } \\
\text { - Accomplish writing } \\
\text { assignments }\end{array}$ & $\begin{array}{l}\text { Getting } \\
\text { started with a } \\
\text { few lines }\end{array}$ \\
\hline 4 & NTP & M & EFL & $\begin{array}{l}\text { - Support self-awareness } \\
\text { - Modify writing practices }\end{array}$ & $\begin{array}{l}\text { Getting } \\
\text { started with a } \\
\text { few lines }\end{array}$ \\
\hline 5 & SMB & M & Literature & $\begin{array}{l}\text { - Identify areas of writing } \\
\text { features } \\
\text { - Seize writing } \\
\text { opportunities as well }\end{array}$ & $\begin{array}{l}\text { Exploration } \\
\text { of ideas }\end{array}$ \\
\hline 6 & FSB & $\mathrm{M}$ & Linguistics & $\begin{array}{l}\text { - Understand writing issues } \\
\text { - Ignite self-exploratory } \\
\text { capability }\end{array}$ & $\begin{array}{l}\text { Fear of } \\
\text { making } \\
\text { mistakes }\end{array}$ \\
\hline 7 & AMM & $\mathrm{F}$ & Literature & $\begin{array}{l}\text { - Solve writing problems } \\
\text { - Reflect writing benefits }\end{array}$ & $\begin{array}{l}\text { Exploration } \\
\text { of ideas }\end{array}$ \\
\hline 8 & DK & $\mathrm{M}$ & EFL & $\begin{array}{l}\text { - Think logically } \\
\text { - Reconsider revisions }\end{array}$ & $\begin{array}{l}\text { Fear of } \\
\text { making } \\
\text { mistakes }\end{array}$ \\
\hline 9 & ASS & $\mathrm{F}$ & EFL & $\begin{array}{l}\text { - Recognize writing } \\
\text { weaknesses } \\
\text { - Find out the solutions } \\
\text { towards them }\end{array}$ & $\begin{array}{l}\text { Exploration } \\
\text { of ideas }\end{array}$ \\
\hline 10 & SA & $\mathrm{F}$ & EFL & $\begin{array}{l}\text { - Construct an } \\
\text { understanding of writing } \\
\text { practices } \\
\text { - Connect between theories } \\
\text { and practices }\end{array}$ & $\begin{array}{l}\text { Fear of } \\
\text { making } \\
\text { mistakes }\end{array}$ \\
\hline 11 & YA & $\mathrm{F}$ & Linguistics & $\begin{array}{l}\text { - Develop writing skills } \\
\text { - Explore ideas based on } \\
\text { different topics }\end{array}$ & $\begin{array}{l}\text { Exploration } \\
\text { of ideas }\end{array}$ \\
\hline
\end{tabular}




\section{Data Analysis Technique \\ Data reduction}

Data reduction is a process of selecting, focusing, simplifying, abstracting and transforming the 'raw' data into a systematic analysis or a coding system. It aims to describe how the research questions can be answered, or how the research problems are responded to.

\section{Data Classification}

Types of Data

Two types of data include the primary data consisting of 28 original research proposals compiled by the fourth-semester students at the English Education Department of Universitas Sarjanawiyata Tamansiswa, Yogyakarta, Indonesia. The researchers chose undergraduate research proposals for two reasons: (a) they were written in the English language and contained academic phrases as linguistic features, and (b) the documents have the level of difficulties in that the researchers were challenged to study them. The secondary data comprise the results of interviews with 11 out of 28 undergraduate research proposal writers. They gave the researchers data or information about the praxis of academic writing phrases. The secondary data supported the primary data.

\section{Data Coding}

From the primary data, the researchers made two code categories, namely putting the academic writing phrases into groups, and studying them to form meaning components of the documents. From the secondary data, the researchers made strategy codes (Ary, Jacobs \& Sorensen, 2009). Each indicator of the recorded and transcribed interviews was coded (as a kind of convention). The category codes aim to make the information unit of tape-recorded interviews concerning vital perspectives on the benefits of and problems in constructing academic writing phrases.

\section{Data Collection Procedures}

There were two kinds of data collection procedures. First, the preparation phase consists of two steps, namely (i) choosing research proposals to be researched, and (ii) contacting twenty eight research proposal writers at the English Education Department of Universitas Sarjanawiyata Tamansiswa, Yogyakarta, Indonesia. Second, the implementation phase covers four elements, namely (i) studying the documents, (ii) analysing the components of academic writing phrases, (iii) conducting unstructured tape-recorded interviews with participants, collecting the data, transcribing, and (iv) analysing them.

\section{Data Analysis Procedures}

The researchers paid attention to two domains of analyses, such as the analysis of primary data limited to the categories of academic writing phrases, and the analysis of interview data (secondary data). The interview questions were used to share "emerging views on theories and practices" (Willis, 2015) of academic writing phrases, benefits of and problems in constructing such phrases, as illustrated in the table 2. 
Table 2. The data blueprint

\begin{tabular}{|c|c|c|c|c|}
\hline No & Research Questions & How & Who & What \\
\hline 1 & $\begin{array}{l}\text { What are the types of } \\
\text { academic writing phrases } \\
\text { in EFL students' research } \\
\text { proposals? }\end{array}$ & $\begin{array}{l}28 \\
\text { documents } \\
\text { of research } \\
\text { proposals }\end{array}$ & $\begin{array}{l}28 \quad \text { EFL } \\
\text { university } \\
\text { students }\end{array}$ & $\begin{array}{l}\text { Content } \\
\text { (Primary data) }\end{array}$ \\
\hline 2 & $\begin{array}{l}\text { What benefits do EFL } \\
\text { students obtain from } \\
\text { constructing academic } \\
\text { writing phrases in the } \\
\text { research proposals? }\end{array}$ & Interview & $\begin{array}{ll}11 & \text { EFL } \\
\text { students } & \end{array}$ & $\begin{array}{l}\text { Benefits } \\
\text { (Secondary data) }\end{array}$ \\
\hline 3 & $\begin{array}{l}\text { What problems do EFL } \\
\text { students face while } \\
\text { constructing academic } \\
\text { writing phrases in the } \\
\text { research proposals? }\end{array}$ & Interview & $\begin{array}{ll}11 & E F L \\
\text { students } & \end{array}$ & $\begin{array}{l}\text { Problems } \\
\text { (Secondary data) }\end{array}$ \\
\hline
\end{tabular}

\section{Findings and Discussion}

\section{Incorporating Academic Writing Phrases into Research Proposals}

This research explores how EFL university students use academic writing phrases in a wide variety of contexts in their research proposals. The following academic phrases are categorized as a medium level of awareness (Çandarl1, 2018) through which students highlight the significance of the topic under research.

a. One of the critical parts of understanding a language is to communicate well. Paper 01)

b. Using Facebook as [a] learning media is an instrumental part of education. (Paper 02)

These phrases are used in the background section of the study, indicating the topic introduction incommensurate with the clarity, fluency, and accuracy of expressions. The academic sentences can be framed in such a way that students can re-construct them differently. The models of such sentences are contextually used for certain academic purposes.

Other academic phrases deal with the goal of the study, and it corresponds to particular objectives that should be mentioned earlier and achieved later in the discussion section, as stated as follows.

a. The goal of language teaching is to transfer knowledge to EFL students. (Paper 04)

b. This research will examine the use of mobile phones for academic writing purposes among students, faculty members, and teachers. (Paper 21)

This model of academic phrases has an educational purpose in that EFL students learn to be creative in creating other forms of academic phrases contextually, and each of them is not a formulaic expression. Instead, the more students are creative in constructing the academic sentences, the better their research proposals will be in terms of the complexity and acceptability of the sentences. 
The significance of the study is another concern of the research that directs researchers to the creation of academic phrases and the formulations of priorities, as highlighted in the following evidence.

a. This research will give the contribution to the teachers, students and [other] researchers. (Paper 19)

b. This research will give significant benefits to the teaching technique and learning media. (Paper 11)

These academic phrases investigate the research contributions that might be important to consider. Students need to formulate different academic sentences contextually by following the model provided.

The fundamental issue of the study determines how researchers put forward the scope of topics discussed. The following academic phrases are closely related to the literary work and linguistics that portray the actual concentration of the research. The construction of the academic phrases is a repetition of the same form that frequent words (Vincent, 2013) correspond to the basic categories (Ruan, 2017).

a. This study will [focus] on students' responses towards the use of English movies. (Paper 12)

b. The study will [focus] on analysing [a] woman's character in the movie. (Paper 16)

The reference segment in these sentences seeks to shed light on writers' positions in which the research proposals show fewer paraphrasing techniques. As mostly evidenced, however, the research proposal writers describe a general but relevant review of the literature using simple academic phrases, as follows.

a. According to Reynolds (2016), lack of knowledge in the conversational usage of collocations results in incompetent writing. (Paper 01)

b. $\quad$ Ur (1996) defined that vocabulary is the words a teacher uses in the teaching of English as a foreign language. (Paper 05)

These academic phrases can be re-constructed to grasp their basic categories (Ruan, 2017) and contextual uses, aiming at mapping out the consistency of writers in providing critical theories or ideas so that readers can understand the current reviews highlighted.

A review of literature should be written systematically, meaning that it has a wide variety of academic phrases to put forward. More regularly, investigating ideas or theories is an area of concern, and how referencing systems are carried out in varied disciplines, as shown in the following example.

a. Through her work, Malone (2018) indicated that children stories are based on social experiences in local environments. (Paper 06)

b. Venuti (1998:240) shows that a translator has to choose a foreign language text and sets a strategy to translate it. (Paper 02)

The textual evidence in such academic phrases principally supports a line of argument that indicators show variables to exemplify. Research proposal writers use the reporting verbs such as show and indicate to verify theories or ideas. Their reconstructions and conceptual patterns should be applied in different situations. 
The construction of a literature review determines the meaning of texts that bridges a gap between the textual evidence and its context. As the documents are written regularly, meanings should be expressed as clearly as possible. Using wide-ranging academic phrases, each part of the documents puts forward clearcut messages in that readers can digest ideas or theories, as elaborated in the following example.

a. Majchrzak (2018) states that bilingualism is not only concerned with two language systems, but also the perfect individual speakers of the languages. (Paper 04)

b. Lamb (2018) mentioned that children can be readers of different literary texts in early modern cultures. (Paper 03)

The reporting verbs in such sentences are used to highlight the writers' ideas on both bilingualism and children as readers of literary texts. The messages behind these two statements are re-constructed in other pertinent research proposals contextually.

In general, the most frequently used academic writing phrase in the research proposals is a mode of explaining key terms (31.3\%), and this emergence is influenced by EFL students' frequency of listing, clarifying, and defining key words. The dynamic nature of EFL issues in higher education designates the objectives of the study $(22.3 \%)$, the importance of the topic $(12.5 \%)$, and the introduction to the subject (13.4). What follows is a review of previous studies $(10.7 \%)$ that necessarily has led to the background information of citations, and criticism. However, EFL students undergo a references deficiency within the gamut of both learning materials and research proposals. The highlighted scope of the topic $(9.8 \%)$ is a core component of academic writing. Still, EFL students face practical difficulties in formulating the research scope, as shown in the following table.

Table 3. Categories of academic writing phrases in the EFL students' research proposals, as evidenced in 224 samples of data

\begin{tabular}{|l|l|c|c|}
\hline No & \multicolumn{1}{|c|}{$\begin{array}{c}\text { Categories of Academic Writing } \\
\text { Phrases }\end{array}$} & $\begin{array}{c}\text { Number of } \\
\text { Frequency }\end{array}$ & $\begin{array}{c}\text { Percentage } \\
\mathbf{( \% )}\end{array}$ \\
\hline 1 & Introducing the topic & 30 & 13.4 \\
\hline 2 & Significance of the topic & 28 & 12.5 \\
\hline 3 & Scope of the topic & 22 & 9.8 \\
\hline 4 & Objectives of the study & 50 & 22.3 \\
\hline 5 & Review of prior research & 24 & 10.7 \\
\hline 6 & Explaining the key terms & 70 & 31.3 \\
\hline \multicolumn{2}{r|}{ Total } & 224 & 100 \\
\hline
\end{tabular}

The Benefits of Constructing Academic Writing Phrases

To construct academic writing phrases is one of the essential activities for EFL students. Its contribution to the betterment of writing competence is genuine and positive to develop writing skills, intellectual abilities, critical reflection, and imagination. Arguments in each section of the research proposals are presented to pursue the writing skills, background knowledge and the linkage of logical ideas. Through inductive and deductive thinking processes or a combination of 
both, EFL students attempt to improve writing performances that require technical skills, self-confidence, and intelligence.

Academic writing aims to enhance mechanical activities such as taking notes and defining words from a dictionary, remembering or documenting them. Likewise, writing essays or scientific works are depleted with detailed definitions of conditions needed to claim propositions. The essence of scientific writing is inseparable from the effort to classify terms in a dictionary that begins by listing the word categories. The actual book of concepts can help EFL students develop writing skills while accomplishing assignments.

The consistent practice of academic writing phrases represents the sequence of events. EFL students seize the opportunities to emphasize procedural steps, clues, series of events, or relationships between ideas, between the causes of problems. This effort is based on the standard of accuracy and clarity of using words logically and critically. Academic writing activities become an integral part of their learning experience enriched with knowledge fundamental to build critical thinking, especially those involving comparative studies of literature, EFL, and linguistics. Through academic writing, EFL students not only present information from different viewpoints, but also restructure and re-evaluate theories to make them more attractive, salient, and interconnected, as excerpted in the table below.

Table 4. The participants' profiles and views on the academic writing phrases

\begin{tabular}{|l|c|c|c|l|}
\hline No & $\begin{array}{c}\text { Names } \\
\text { by } \\
\text { Initials }\end{array}$ & Gender & Interest & $\begin{array}{l}\text { Views on Constructing Academic Writing } \\
\text { Phrases }\end{array}$ \\
\hline 1 & HN & M & EFL & $\begin{array}{l}\text { - Pursue knowledge of EFL writing } \\
\text { - Improve writing competence }\end{array}$ \\
\hline 2 & ANM & M & EFL & $\begin{array}{l}\text { - Encourage self-confidence } \\
\text { - Challenge writing accuracies }\end{array}$ \\
\hline 3 & AP & F & Literature & $\begin{array}{l}\text { - Hone writing skills } \\
\text { - Accomplish writing assignments }\end{array}$ \\
\hline 4 & NTP & M & EFL & $\begin{array}{l}\text { - Support self-awareness } \\
\text { - Modify writing practices }\end{array}$ \\
\hline 5 & SMB & M & Literature & $\begin{array}{l}\text { - Identify areas of writing features } \\
\text { - Seize writing opportunities as well }\end{array}$ \\
\hline 6 & FSB & M & Linguistics & $\begin{array}{l}\text { - Understand writing issues } \\
\text { - Ignite self-exploratory capability }\end{array}$ \\
\hline 7 & AMM & F & Literature & $\begin{array}{l}\text { - Solve writing problems } \\
\text { - Reflect writing benefits }\end{array}$ \\
\hline 8 & DK & M & EFL & $\begin{array}{l}\text { - Think logically } \\
\text { - Reconsider revisions }\end{array}$ \\
\hline 9 & ASS & F & EFL & $\begin{array}{l}\text { - Recognize writing weaknesses } \\
\text { - Find out the solutions towards them }\end{array}$ \\
\hline 10 & SA & F & EFL & $\begin{array}{l}\text { - Construct an understanding of writing } \\
\text { practices } \\
- \text { Connect between theories and practices }\end{array}$ \\
\hline 11 & YA & F & Linguistics & $\begin{array}{l}\text { - Develop writing skills } \\
\text { - Explore ideas based on different topics }\end{array}$ \\
\hline
\end{tabular}


The realm of academic writing phrases is directly related to the linguistic features including the lexical bundles (Thonney, 2012) and the activities of studying and interpreting the topic of discussion. Writing activities involve the domain of a problem analysis by comparing, grouping, sequencing the debate, and summarizing it into logical, transparent, and straightforward sections. However, the study of problems depends entirely on how the EFL students unpack the ideas on their minds and communicate them more clearly, and straightforwardly, and how they rest on a single hypothesis or even more to analyse the research problems.

The practices of writing academic phrases encourage EFL students to brainstorm ideas (a writing strategy carried out by grouping ideas, words, or concepts related to the topic of writing), drafts, editing, and revisions. As a learning process, academic writing is more than just creating the final products, but making a series of academic writing skills (Ebadi \& Rahimi, 2018; Ebadi \& Rahimi, 2019) more likely towards achieving maximum results. It serves as a practical means of knowledge inquiry (Lin, 2016) that features a typical tone to demonstrate EFL writing theories, glaring facts, and arguments.

\section{EFL Students' Problems in Constructing Academic Writing Phrases}

The interview results show that EFL students face a number of problems in constructing academic writing phrases in their research proposals, as follows.

\section{Problem 1 - Getting Started with a Few Lines}

The most challenging part of writing a research proposal is to get started with a few lines of sentences that mainly contains academic phrases (Participants 3). As students' constructions of sentences should be aware of the accuracy principle, the first and most common pitfall is how to get ahead full of ideas and put conceptual frameworks into words.

The following quote illustrates, "It's roughly hard to start with the academic phrases. It feels like a pitfall" (Participant 1). As an advanced framework, another participant stated that academic phrases are specific terms that seem difficult to apply because integrated components such as phrasal quality, linguistic advancement, acceptability, and clarity are worth prioritizing (Participant 4).

\section{Problem 2 - Exploration of Ideas}

As struggling proposal writers, participants found it difficult to express ideas because of the background knowledge, and linguistic competence. As the participants were in the second year of undergraduate studies (at the time of writing their research proposals), they realized how their limited knowledge capacity determined further exploration of ideas using acceptable academic writing phrases (Participants 8 \& 11).

Other participants stated, "[I was in] the fourth semester at the time, I didn't understand the academic phrases" (Participant 5), and "... the most difficult part was how to explore ideas, particularly when I was in a position of having an inadequate understanding of academic phrases" (Participant 7). 


\section{Problem 3 - Fear of Making Mistakes}

As writing is a productive skill, a participant stated that they could not outperform in writing their research proposals mostly resulting from the fact that they are afraid of making mistakes (Participant 2). Even though making mistakes is human, all difficulties and challenges are derived from low writing competence. Students need to practice writing as much as they can while learning from the mistakes they make. Therefore, academic writing is not solely a reflection of productive and creative ideas, but it is merely a trial and error practice of learning to be a writer (Participant 8).

Typical answers by a participant included, "...I'm afraid of making mistakes [when] writing academic essays. I sometimes feel ashamed my writing is incorrect; consequently, when writing, I'm afraid of making mistakes" (Participant 6). Another participant emphasized that a minor mistake leads to inferior feelings, and feeling ashamed may indirectly result from the low mastery of the topic and the matter of poor writing competence (Participant 10).

\section{Conclusion}

The academic phrases are typically beneficial for EFL university students in the praxis of writing for educational purposes such as writing the introduction and literature review of research proposals. The writing components of academic phrases include accuracy, clarity, and complexity of expressions, and (re)constructions of patterns to help students create other academic phrases contextually. Lecturers introduce the academic writing phrases to EFL university students as one of the solutions toward the understanding of the language usage in the research proposals within a semester course. This is the essence of developing their writing skills and potentials, particularly when they learn to display components of academic writing phrases concisely but precisely. Embedded in every writing practice is the commitment to seize opportunities for applying given theories. Practical writing techniques are also necessary to capture EFL students' creativity, cooperation, engagement, and communication. However, as the interview results proved, EFL university students find a wide variety of writing problems such as a pitfall of getting started with a few lines of ideas, the exploration of topical ideas, and fear of making mistakes. To begin writing is the most challenging part because research proposal writers should build understandable concepts that represent meanings of academic phrases.

\section{Limitations and Pedagogical Implications}

The current research suggests a broader framework of EFL students' academic writing, but it indicates two weaknesses related to the benefits of and problems in constructing academic writing phrases contextually. First, the results of this research stem from a small size of data samples in a geographical location. Second, EFL students' perspectives and beliefs on academic writing and its benefits and problems do not represent other principles of academic writing phrases. For this reason, future researchers are recommended to use a large size of data samples in different settings and investigate other variables on the problem-solving schemes, for example, how EFL students re-construct academic writing phrases to get insights into a more complete way of understanding the critical issues. 
The main emphasis on using academic writing phrases in research proposals leads to pedagogical implications in a global context. First, academic writing helps EFL students broaden their background knowledge, and writing skills through "critical writing practices" (Huang, 2012). The implementation of this academic writing is limited to the EFL academic phrases beyond the critical writing skills, namely describing, evaluating and analysing ideas with critical eyes. Second, writing lecturers may assume responsibility for providing EFL students with academic writing phrases to develop their critical thinking skills. That is why this research investigates an EFL context of academic writing to produce different phrases incorporated into research proposals.

\section{Acknowledgement}

We would like to express our gratitude to anonymous reviewers and editors of International Journal of Learning, Teaching and Educational Research for their constructive criticism, comments, and suggestions on the initial drafts of this article.

\section{References}

Abbas, M. A., Hammad, S., Hwang, G.-J., Khan, S., \& Gilani, S. M. M. (2020). An assistive environment for EAL academic writing using formulaic sequences classification. Interactive Learning Environments, 1-15. https://doi.org/10.1080/10494820.2020.1789670

Abednia, A., Hovassapian, A., Teimournezhad, S., \& Ghanbari, N. (2013). Reflective journal writing: Exploring in-service EFL teachers' perceptions. System, 41(3), $503-$ 514. https://doi.org/10.1016/j.system.2013.05.003

Afshunpour, N., \& Memari, M. (2014). Interlingual Transfer of Idioms by Persian Learners in EFL Sentence Writing. Procedia - Social and Behavioral Sciences, 98, 44-51. https:// doi.org/10.1016/j.sbspro.2014.03.387

Akbari, N. (2017). Lexical diversity and the use of academic and lower frequency words in the academic writing of EFL students. Australian Review of Applied Linguistics, 40(1), 3-18. https://doi.org/10.1075/aral.40.1.02akb

Ansarifar, A., Shahriari, H., \& Pishghadam, R. (2018). Phrasal complexity in academic writing: A comparison of abstracts written by graduate students and expert writers in applied linguistics. Journal of English for Academic Purposes, 31, 58-71. https://doi.org/10.1016/j.jeap.2017.12.008

Ary, D., Jacobs, L. C., \& Sorensen, C. (2009). Introduction to Research in Education. (C. Shortt, Ed.) (8th Editio). Belmont, California: Wadsworth.

Badley, G. F. (2019). Post-Academic Writing: Human Writing for Human Readers. Qualitative Inquiry, 25(2), 180-191. https:/ / doi.org/10.1177/1077800417736334

Badley, G. F. (2020). Why and How Academics Write. Qualitative Inquiry, 26(3-4), 247-256. https:// doi.org/10.1177/1077800418810722

Bai, B., Wang, J., \& Nie, Y. (2020). Self-efficacy, task values and growth mindset: what has the most predictive power for primary school students' self-regulated learning in English writing and writing competence in an Asian Confucian cultural context? Cambridge Journal of Education, 1-20. https://doi.org/10.1080/0305764X.2020.1778639

Barrot, J. S. (2020). Effects of Facebook-based e-portfolio on ESL learners' writing performance. Language, Culture and Curriculum, 1-17. https:// doi.org/10.1080/07908318.2020.1745822

Beck, S. W., \& Jeffery, J. V. (2007). Genres of high-stakes writing assessments and the 
construct of writing competence. Assessing Writing, 12(1), 60-79. https://doi.org/10.1016/j.asw.2007.05.001

Benelhadj, F. (2019). Discipline and genre in academic discourse: Prepositional Phrases as a focus. Journal of Pragmatics, 139, 190-199. https:// doi.org/10.1016/j.pragma.2018.07.010

Berge, K. L., Evensen, L. S., \& Thygesen, R. (2016). The Wheel of Writing: a model of the writing domain for the teaching and assessing of writing as a key competency. $\begin{array}{llll}\text { The Curriculum } & \text { Journal, 27(2), 172-189. }\end{array}$ https:// doi.org/10.1080/09585176.2015.1129980

Biber, D., Gray, B., Staples, S., \& Egbert, J. (2020). Investigating grammatical complexity in L2 English writing research: Linguistic description versus predictive measurement. Journal of English for Academic Purposes, 46, 100869. https:// doi.org/10.1016/j.jeap.2020.100869

Birjandi, P., \& Hadidi Tamjid, N. (2012). The role of self-, peer and teacher assessment in promoting Iranian EFL learners' writing performance. Assessment $\mathcal{E}$ Evaluation in Higher Education, 37(5), 513-533. https:/ / doi.org/10.1080/02602938.2010.549204

Boddy, C. (2012). The Nominal Group Technique: an aid to Brainstorming ideas in research. Qualitative Market Research: An International Journal, 15(1), 6-18. https://doi.org/10.1108/13522751211191964

Cai, L. J. (2016). An exploratory study on an integrated genre-based approach for the instruction of academic lexical phrases. Journal of English for Academic Purposes, 24, 58-74. https://doi.org/10.1016/j.jeap.2016.09.002

Çandarlı, D. (2018). Changes in L2 writers' self-reported metalinguistic knowledge of lexical phrases over one academic year. The Language Learning Journal, 1-17. https://doi.org/10.1080/09571736.2018.1520914

Casanave, C. P. (2019). Does Writing for Publication Ever Get Easier? Some Reflections from an Experienced Scholar. In Novice Writers and Scholarly Publication (pp. 135151). Cham: Springer International Publishing. https://doi.org/10.1007/978-3319-95333-5_8

Chen, W. (2019). Profiling Collocations in EFL Writing of Chinese Tertiary Learners. RELC Journal, 50(1), 53-70. https://doi.org/10.1177/0033688217716507

Clifton, C., \& Frazier, L. (2012). Interpreting Conjoined noun Phrases and Conjoined Clauses: Collective versus Distributive Preferences. Quarterly Journal of Experimental Psychology, 65(9), 1760-1776. https://doi.org/10.1080/17470218.2012.667425

Cohen, L., Manion, L., \& Morrison, K. (2000). Research Methods in Education. Fifth Edition. London: Routledge Falmer, Francis \& Taylor Group

Concha, S., \& Paratore, J. R. (2011). Local Coherence in Persuasive Writing: An Exploration of Chilean Students' Metalinguistic Knowledge, Writing Process, and Writing Products. Written Communication, 28(1), 34-69. https://doi.org/10.1177/0741088310383383

Crouch, M., \& McKenzie, H. (2006). The logic of small samples in interview-based qualitative research. Social Science Information, 45(4), 483-499. https://doi.org/10.1177/0539018406069584

Davis, M., \& Morley, J. (2015). Phrasal intertextuality: The responses of academics from different disciplines to students' re-use of phrases. Journal of Second Language Writing, 28, 20-35. https:// doi.org/10.1016/j.jslw.2015.02.004

DeCarrico, J., \& Nattinger, J. R. (1988). Lexical phrases for the comprehension of academic lectures. English for Specific Purposes, 7(2), 91-102. https:// doi.org/10.1016/08894906(88)90027-0

Ebadi, S., \& Rahimi, M. (2018). An exploration into the impact of WebQuest-based 
classroom on EFL learners' critical thinking and academic writing skills: a mixedmethods study. Computer Assisted Language Learning, 31(5-6), 617-651. https://doi.org/10.1080/09588221.2018.1449757

Ebadi, S., \& Rahimi, M. (2019). Mediating EFL learners' academic writing skills in online dynamic assessment using Google Docs. Computer Assisted Language Learning, 32(5-6), 527-555. https://doi.org/10.1080/09588221.2018.1527362

Elfiondri, E. (2019). Inter-lingual errors of Indonesian-English in relation to English composition: The case of Bung Hatta University EFL Students, Indonesia, Asian EFL Journal, 24(4.1), 45-60. https://www.asian-efl-journal.com/monthlyeditions-new/2019-monthly-journals/volume-24-issue-4-1-2019/

Farahian, M., \& Avarzamani, F. (2018). The impact of portfolio on EFL learners' metacognition and writing performance. Cogent Education, 5(1). https:// doi.org/10.1080/2331186X.2018.1450918

Galloway, E.P., Stude, J., \& Uccelli, P. (2015). Adolescents' metalinguistic reflections on the academic register in speech and writing. Linguistics and Education, 31, 221-237. https://doi.org/10.1016/j.linged.2014.10.006

Golpour, F., Ahour, T., Ahangari, S., \& Lu, X. (2019). Iranian EFL teachers' beliefs and practices regarding writing activities and class organization. Cogent Education, 6(1). https://doi.org/10.1080/2331186X.2019.1651812

Habibie, P. (2019). To Be Native or Not to Be Native: That Is Not the Question. In Novice Writers and Scholarly Publication (pp. 35-52). Cham: Springer International Publishing. https://doi.org/10.1007/978-3-319-95333-5_3

Imaniah, I., Mayuni, I., \& Lustyantie, N. (2019). The student's academic writing skill in terms of academic procrastination, self-esteem and reading habit at Muhammadiyah University of Tangerang, Asian EFL Journal, 24(4.1), 118-127. https://www.asian-efl-journal.com/monthly-editions-new/2019-monthlyjournals/volume-24-issue-4-1-2019/

Huang, S. (2012). The integration of 'critical' and 'literacy' education in the EFL curriculum: expanding the possibilities of critical writing practices. Language, Culture and Curriculum, 25(3), 283-298. https://doi.org/10.1080/07908318.2012.723715

Hyland, K. (2008). As can be seen: Lexical bundles and disciplinary variation. English for Specific Purposes, 27(1), 4-21. https://doi.org/10.1016/j.esp.2007.06.001

Kaweera, C. (2013). Writing Error: A Review of Interlingual and Intralingual Interference in EFL Context. English Language Teaching, 6(7). https://doi.org/10.5539/elt.v6n7p9

Kerz, E., \& Wiechmann, D. (2015). Register-Contingent Entrenchment of Constructional Patterns. Journal of English Linguistics, 43(1), 61-85. https:// doi.org/10.1177/0075424214564364

Kozawa, S., Sakai, Y., Sugiki, K., \& Matsubara, S. (2010). Automatic Extraction of Phrasal Expressions for Supporting English Academic Writing (pp. 485-493). https://doi.org/10.1007/978-3-642-14616-9_47

Lamb, E. (2018). Reading Children in Early Modern Culture Early Modern Literature in History. Belfast: Palgrave Macmillan.

Lan, G., Lucas, K., \& Sun, Y. (2019). Does L2 writing proficiency influence noun phrase complexity? A case analysis of argumentative essays written by Chinese students in a first-year composition course. System, 85, 102116. https://doi.org/10.1016/j.system.2019.102116

Lan, G., \& Sun, Y. (2019). A corpus-based investigation of noun phrase complexity in the L2 writings of a first-year composition course. Journal of English for Academic Purposes, 38, 14-24. https:// doi.org/10.1016/j.jeap.2018.12.001 
Leroy, G., Kauchak, D., \& Hogue, A. (2016). Effects on Text Simplification: Evaluation of Splitting Up Noun Phrases. Journal of Health Communication, 21(sup1), 18-26. https://doi.org/10.1080/10810730.2015.1131775

Li, J., \& Schmitt, N. (2009). The acquisition of lexical phrases in academic writing: A longitudinal case study. Journal of Second Language Writing, 18(2), 85-102. https:// doi.org/10.1016/j.jslw.2009.02.001

Lin, Z. (2016). Context-model-based instruction in teaching EFL writing: A narrative inquiry. Cogent Education, 3(1). https:// doi.org/10.1080/2331186X.2016.1154258

Liu, D., \& Myers, D. (2020). The most-common phrasal verbs with their key meanings for spoken and academic written English: A corpus analysis. Language Teaching Research, 24(3), 403-424. https:// doi.org/10.1177/1362168818798384

Majchrzak, O. (2018). Learner Identity and Learner Belief in EFL Writing Second Language Learning and Teaching. Lodz: Springer International Publishing AG.

Malone, K. (2018). Children in the Anthropocene Rethinking Sustainability and Child Friendliness in Cities. Milperra: Palgrave Macmillan.

Mann, S. (2016). The Research Interview. The Research Interview. https://doi.org/10.1057/9781137353368

Miller, J. J., Grise-Owens, E., Drury, W., \& Rickman, C. (2018). Teaching NoteDeveloping a Professional Writing Course Using a Holistic View of Competence. Journal of Social Work Education, 54(4), 709-714. https://doi.org/10.1080/10437797.2018.1474152

Moret, M., Reuzel, R., van der Wilt, G. J., \& Grin, J. (2007). Validity and Reliability of Qualitative Data Analysis: Interobserver Agreement in Reconstructing Interpretative Frames. Field Methods, 19(1), 24-39. https://doi.org/10.1177/1525822X06295630

Morley, J. (2015). Academic phrasebank: A compendium of commonly used phrasal elements in academic English in PDF format 2014b edition. The University of Manchester.

Morse, J. M., Barrett, M., Mayan, M., Olson, K., \& Spiers, J. (2002). Verification Strategies for Establishing Reliability and Validity in Qualitative Research. International Journal of Qualitative Methods, 1(2), 13-22. https:// doi.org/10.1177/160940690200100202

Mostafa, T., \& Crossley, S. A. (2020). Verb argument construction complexity indices and L2 writing quality: Effects of writing tasks and prompts. Journal of Second Language Writing, 49, 100730. https://doi.org/10.1016/j.jslw.2020.100730

Mur-Dueñas, P. (2019). The Experience of a NNES Outer Circle Novice Scholar in Scholarly Publication. In Novice Writers and Scholarly Publication (pp. 97-115). Cham: Springer International Publishing. https://doi.org/10.1007/978-3-31995333-5_6

Myhill, D., Jones, S., \& Wilson, A. (2016). Writing conversations: fostering metalinguistic discussion about writing. Research Papers in Education, 31(1), 23-44. https://doi.org/10.1080/02671522.2016.1106694

Nagao, A. (2019). The SFL genre-based approach to writing in EFL contexts. Asian-Pacific Journal of Second and Foreign Language Education, 4(1), 6. https:// doi.org/10.1186/s40862-019-0069-3

Nuccorini, S. (2006). In search of 'phraseologies.' European Journal of English Studies, 10(1), 33-47. https://doi.org/10.1080/13825570600590879

Oakey, D. (2020). Phrases in EAP academic writing pedagogy: Illuminating Halliday's influence on research and practice. Journal of English for Academic Purposes, 44, 100829. https:// doi.org/10.1016/j.jeap.2019.100829

Parkinson, J., \& Musgrave, J. (2014). Development of noun phrase complexity in the 
writing of English for Academic Purposes students. Journal of English for Academic Purposes, 14, 48-59. https:// doi.org/10.1016/j.jeap.2013.12.001

Powers, D. E., Fowles, M. E., \& Welsh, C. K. (2001). Relating Performance on a Standardized Writing Assessment to Performance on Selected Academic Writing Activities. Educational Assessment, 7(3), 227-253. https://doi.org/10.1207/S15326977EA0703_03

Qin, W., \& Uccelli, P. (2020). Beyond linguistic complexity: Assessing register flexibility in EFL writing across contexts. Assessing Writing, 45, 100465. https://doi.org/10.1016/j.asw.2020.100465

Rahman, Z. A. A. A. (2013). The Use of Cohesive Devices in Descriptive Writing by Omani Student-Teachers. SAGE Open, 3(4), 215824401350671. https://doi.org/10.1177/2158244013506715

Rakedzon, T., \& Baram-Tsabari, A. (2017). Assessing and improving L2 graduate students' popular science and academic writing in an academic writing course. Educational Psychology, 37(1), 48-66. https://doi.org/10.1080/01443410.2016.1192108

Ratminingsih, N. M., Marhaeni, A. A. I. N., \& Vigayanti, L. P. D. (2018). Self-Assessment: The Effect on Students' Independence and Writing Competence. International Journal of Instruction, 11(3), 277-290. https:/ / doi.org/10.12973/iji.2018.11320a

Reynolds, B. L. (2016). Action Research: Applying a Bilingual Parallel Corpus Collocational Concordancer to Taiwanese Medical School EFL Academic Writing. RELC Journal, 47(2), 213-227. https://doi.org/10.1177/0033688215619518

Roehr, K. (2008). Metalinguistic Knowledge and Language Ability in University-Level L2 $\begin{array}{llll}\text { Learners. } & \text { Applied } & \text { Linguistics, } & \text { 29(2), }\end{array}$ https://doi.org/10.1093/applin/amm037

Rojo, J. L. (2018). Phraseology as indicator for translation quality assessment of museum texts: A corpus-based analysis. Cogent Arts $\mathcal{E}$ Humanities, 5(1). https:// doi.org/10.1080/23311983.2018.1442116

Ruan, Z. (2017). Lexical Bundles in Chinese Undergraduate Academic Writing at an English Medium University. RELC Journal, 48(3), 327-340. https:// doi.org/10.1177/0033688216631218

Sanders, C. B., \& Cuneo, C. J. (2010). Social Reliability in Qualitative Team Research. Sociology, 44(2), 325-343. https://doi.org/10.1177/0038038509357194

Smith, M. A. S (2004). In Two Minds about Grammar: on the Interaction of Linguistic and Metalinguistic Knowledge in Performance. Transactions of the Philological Society, 102(2), 255-280. https://doi.org/10.1111/j.0079-1636.2004.00137.x

Sosenko, F. (2012). Non-fiction Literature and Interpretive/Qualitative Research Methods: Reflections on the Meaning of "Social Science." Methodological Innovations Online, 7(2), 41-63. https://doi.org/10.4256/mio.2012.010

Staples, S., Egbert, J., Biber, D., \& Gray, B. (2016). Academic Writing Development at the University Level. Written Communication, 33(2), 149-183. https://doi.org/10.1177/0741088316631527

Surmann, A. T. (1997). The Effects of Race, Weight, and Gender on Evaluations of Writing Competence. The Journal of Social Psychology, 137(2), 173-180. https:// doi.org/10.1080/00224549709595428

Teng, (Mark) Feng. (2019). The role of metacognitive knowledge and regulation in mediating university EFL learners' writing performance. Innovation in Language Learning and Teaching, 1-15. https:/ / doi.org/10.1080/17501229.2019.1615493

Thonney, T. (2012). "That's Beyond the Scope of This Paper": Analyzing the Functions of a Familiar Phrase in Academic Writing. Rhetoric Review, 31(3), 309-326. https://doi.org/10.1080/07350198.2012.684002

Trotter, R. T. (2012). Qualitative research sample design and sample size: Resolving and 
unresolved issues and inferential imperatives. Preventive Medicine, 55(5), 398-400. https:// doi.org/10.1016/j.ypmed.2012.07.003

Ur, P. (1996). A Course in Language Teaching: Practice of Theory (Cambridge Teacher Training and Development Series). Cambridge: Cambridge University Press.

Venuti, L. (1998). The Scandals of Translation: Towards an Ethics of Difference. London: Routledge.

Vincent, B. (2013). Investigating academic phraseology through combinations of very frequent words: A methodological exploration. Journal of English for Academic Purposes, 12(1), 44-56. https:// doi.org/10.1016/j.jeap.2012.11.007

Wei, Y., \& Lei Lei. (2011). Lexical Bundles in the Academic Writing of Advanced Chinese EFL Learners. RELC Journal, 42(2), 155-166. https://doi.org/10.1177/0033688211407295

Willis, G. B. (2015). Analysis of the Cognitive Interview in Questionnaire Design Understanding Qualitative Research. Oxford: Oxford University Press.

Zarrabi, F., \& Bozorgian, H. (2020). EFL Students' Cognitive Performance during Argumentative Essay Writing: A log-file data analysis. Computers and Composition, 55, 102546. https://doi.org/10.1016/j.compcom.2020.102546 